\title{
Prevalence of MRSA among Clinical Isolates of Staphylococcus aureus and its Antibiotic Susceptibility Pattern at a Tertiary Care Hospital
}

\author{
M.S. Rashmi ${ }^{1 *}$, S. Krishna ${ }^{2}$ and Sumaira Qayoom ${ }^{3}$ \\ ${ }^{1}$ Department of Microbiology,Navodaya Medical College, Raichur, India \\ ${ }^{2}$ Department of Microbiology, Vijaynagara Institute Of Medical Sciences, Ballari, India \\ ${ }^{3}$ Department of Microbiology, SKIMS-MC, JVC, Srinagar, India
}

*Corresponding author

\begin{tabular}{|c|c|}
\hline & A B S T R A C T \\
\hline $\begin{array}{l}\text { Ke y w o r d s } \\
\text { Methicillin Resistant } \\
\text { Staphylococcus } \\
\text { aureus (MRSA), } \\
\text { antibiotic policy, }\end{array}$ & \multirow{3}{*}{$\begin{array}{l}\text { The present study was carried out to isolate Methicillin-Resistant } \\
\text { Staphylococcus aureus (MRSA) in clinical samples. Standard } \\
\text { microbiological and biochemical methods were used to screen } 404 \text { clinical } \\
\text { specimens comprising of pus, urine and blood.58 isolates were MRSA out } \\
\text { of } 194 \text { Staphylococcus aureus isolates. MRSA is increasing. Most MRSA } \\
\text { are resistant to several non-beta lactam antibiotics. Frequent monitoring of } \\
\text { susceptibility patterns of MRSA and formulation of a definite antibiotic } \\
\text { policy may be helpful in decreasing incidence of MRSA infection. }\end{array}$} \\
\hline Article Info & \\
\hline $\begin{array}{l}\text { Accepted: } \\
\text { 29 December } 2016 \\
\text { Available Online: } \\
\text { 10 January } 2017\end{array}$ & \\
\hline
\end{tabular}

\section{Introduction}

Staphylococcus aureus has been recognised for a long time as one of the leading causes of hospital infections all over the world. Most of its strains are opportunistic pathogens that can colonise individuals, without symptoms, for either short or extended period of time, causing disease when the immune system becomes compromised (Maida Sisirak et al., 2010). Changes in pattern of antimicrobial susceptibility of Staphylococcus aureus has been reported worldwide especially in developing countries making antimicrobial agents increasingly less effective in treating bacterial infections (Bukhari et al., 2004). Several mechanisms for Methicillin resistance seen in Staphylococcus aureus has been elucidated. The most important is production of a unique Penicillin binding protein (PBP) that has a low affinity for beta lactam antibiotics and whose effects are determined by several structural genes mec, mecRI, mecI (Krishna et al., 2010). The study was taken up to review and document isolates of MRSA and its susceptibility pattern in various clinical samples, so that measures are taken to decrease the rate of MRSA infection.

\section{Materials and Methods}

A total of 404 clinical isolates were obtained in Department of Microbiology, VIMS, 
Ballari, during the period from 1-1-2014 to 30-6-2014. Antibiotic sensitivity testing was done by Kirby Bauer disc diffusion method (CLSI). MRSA was detected by Cefoxitin $(30 \mu \mathrm{g})$ disk diffusion method. Specimens included pus, urine, blood, from various departments. Specimens were collected taking aseptic measures, they were subjected to preliminary tests like direct gram stain. They were streaked on MacConkey agar, 5\% Blood agar, Mannitol Salt agar. Staphylococcus aureus was identified by colony morphology, gram stain, catalase test, tube coagulase test, DNAse test. Antibiotic sensitivity was done on Mueller Hinton agar using disc diffusion test as outlined by CLSI. The following antibiotics were used to determine the antibiogram. Penicillin, Amoxy-clavulanic acid, Erythomycin, Clindamycin, Amikacin,
Gentamicin, Linezolid, Vancomycin, Teicoplanin, Cotrimoxazole. Methicillin resistance was detected by using Cefoxitin disc. Zone diameter was read after incubation at 35 degree Celsius for full 24 hours. Strains with zone diameter of $<22 \mathrm{~mm}$ for Cefoxitin were regarded as Methicillin Resistant.

\section{Results and Discussion}

During the 6 months study period, a total of 404 samples, were received to Microbiology laboratory. Out of 404 samples, Staphylococcus aureus was isolated from 194 (48.01\%) samples. Out of 194 Staphylococcus aureus isolated, 58(29.89\%) were Methicillin resistant and $136(70.10 \%)$ were Methicillin sensitive.

Table.1 Sample wise distribution of Staphylococcus aureus isolates

\begin{tabular}{|l|l|l|}
\hline Specimens & Number of Strains & Percentage \\
\hline Pus & 82 & $42.26 \%$ \\
\hline Urine & 60 & $30.92 \%$ \\
\hline Blood & 52 & $26.80 \%$ \\
\hline
\end{tabular}

Table.2 Sample wise distribution of MRSA

\begin{tabular}{|l|l|l|}
\hline Specimens & MRSA & Percentage \\
\hline Pus & 28 & $48.27 \%$ \\
\hline Urine & 18 & $31.03 \%$ \\
\hline Blood & 12 & $20.68 \%$ \\
\hline
\end{tabular}

Table.3 Sensitivity patterns of MRSA isolated

\begin{tabular}{|l|l|l|}
\hline Antibiotics & Resistant & Sensitive \\
\hline Penicillin & $58(100 \%)$ & - \\
\hline Amoxyclav & $58(100 \%)$ & - \\
\hline Erythromycin & $58(100 \%)$ & - \\
\hline Clindamycin & $42(72.4 \%)$ & $16(27.58 \%)$ \\
\hline Gentamicin & $58(100 \%)$ & - \\
\hline Amikacin & $16(27.58 \%)$ & $42(72.4 \%)$ \\
\hline Linezolid & - & $58(100 \%)$ \\
\hline Vancomycin & - & $58(100 \%)$ \\
\hline Teicoplanin & - & $58(100 \%)$ \\
\hline Cotrimoxazole & $31(53.44 \%)$ & $27(46.55 \%)$ \\
\hline
\end{tabular}


MRSA strains were maximum from pus(28), followed by urine (18) and blood(12). The sensitivity profile of these isolates were $100 \%$ for Linezolid, $100 \%$ for Vancomycin, $100 \%$ for Teicoplanin, $72.4 \%$ for Amikacin. All MRSA isolates showed $100 \%$ resistance to Penicillin, Amoxyclav, Erythromycin, Gentamicin, Clindamycin, Cotrimoxazole.

The present study shows $29.89 \%$ of MRSA. Similar patterns are seen worldwide as evident from many recorded surveillance studies. MRSA has become increasingly prevalent worldwide (Boutiba-Ben Boubaker et al., 2004). Due to increasing number of infections caused by Methicillin-Resistant Staphylococcus aureus (MRSA) strains, which are now most often multiresistant, therapy has become problematic (Sharp et al., 2004). MRSA spreads by physical contact or transmitted indirectly by contact with towels, clothes, etc. (Andrea Guyot et al., 2006). They are generally multidrug resistant and their therapy entails a huge financial drain on the hospital resources. Good infection control practices with emphasis on strict hand washing can minimise this burden by reducing their transmission. Prudent use of antimicrobial agents is one of the major steps to reduce growing problem of antibiotic resistance (Mulla et al., 2007).

\section{References}

Andrea Guyot, Graham Layer. 2006. MRSA'bug-bear' of a surgical practice: reducing the incidence of MRSA surgical site infections. Ann. R. Coll. Surg. Engl., 88: 222-223.

Boutiba-Ben Boubaker, I., Abbes, R.B., Abdallah, H.B., Mamlouk, K., Mahjoubi, F. et al. 2004. Evaluation of a cefoxitin disk diffusion test for the routine detection of methicillin resistant Staphylococcus aureus. Clin. Microbiol. Infect., 10(8): 762-765.

Bukhari, M.H. et al. 2004. A laboratory study of susceptibility of methicillin resistant Staphylococcus aureus. Pak. J. Med. Sci., 20: 229233.

Charles Brunicardi, F. Dana K.Anderson. Timothy R.Billar, David L.Dunn, John G. Hunter, Jeffrey B. Matthews, Raphael E. Pollock. Schwartz's Principles of Surgery. $9^{\text {th }}$ edition, Part I, Chapter 6, Surgical infections, p. 113133.

Krishna, B.V. et al. 2004. Community acquired methicillin resistant Staphylococcus aureus infection in a south Indian city. Southeastern Asian J. Trop. Med. Pub. Health, 35: 371374.

Maida Sisirak, Amra Zvizdic, Mirsada Hukic. Methicillin Resistant Staphylococcus aureus (MRSA): As A Cause of Nosocomial Wound Infections. Bosnian J. Basic Med. Sci., 10(1): 35-37.

Sharp, S.E., Searchy, C. 2004. Comparision of Mannitol Salt agar and blood agar plates for identification and susceptibility testing of Staphylococcus aureus in specimens from cystic fibrosis patients. J. Clin. Micribiol., 44(12): 4545-4546.

\section{How to cite this article:}

Rashmi, M.S., S. Krishna and Sumaira Qayoom. 2017. Prevalence of MRSA among Clinical Isolates of Staphylococcus aureus and its Antibiotic Susceptibility Pattern at a Tertiary Care Hospital. Int.J.Curr.Microbiol.App.Sci. 6(1): 747-749. doi: http://dx.doi.org/10.20546/ijcmas.2017.601.088 